\title{
ISPITIVANJE GASNIH ANALIZA ARTERIJSKE KRVI U AKUTNOJ RESPIRATORNOJ INSUFICIJENCIJI KOD PACIJENATA SA HRONIČNOM OPSTRUKTIVNOM BOLESTI PLUĆA
}

\author{
ANALYSIS OF ARTERIAL BLOOD GASES IN ACUTE RESPIRATORY FAILURE IN PATIENTS \\ WITH CHRONIC OBSTRUCTIVE PULMONARY DISEASE
}

\author{
Tanja Šobot, Zorislava Bajić, Želimir Erić, Peđa Kovačević, Marinko Vučić
}

\begin{abstract}
Uvod Hronična opstruktivna bolest pluća (HOBP) je jedan od glavnih uzroka morbiditeta $i$ mortaliteta širom svijeta. U toku egzacerbacija HOBP može se javiti akutna respiratorna insuficijencija (ARI) tip 2, koja se karakteriše hiperkapnijom, vrijednošću parcijalnog pritiska ugljendioksida (PaCO2) većom od 6,67 kPa (50 mm Hg), hipoksemijom (snižen PaO2) kao i vrijednošću pH manjom od 7,3.

Cilj rada je utvrditi uticaj mehaničke ventilacije na oksigenacioni $i$ acido-bazni status kod pacijenata sa akutnom hiperkapnijskom respiratornom insuficijencijom na podlozi postojeće HOBP.

Metodologija Retrospektivnom studijom je obuhvaćeno 30 ispitanika koji su liječeni na Klinici intenzivne medicine za nehirurške grane Univerzitetskog kliničkog centra Republike Srpske, tokom 2016. godine. Ispitanici sa razvijenom ARI tip 2 na podlozi HOBP terapijski su bili izloženi izloženi invanzivnoj i/ili neinvanzivnoj mehaničkoj ventilaciji. Kod ispitanika smo analizirali gasne parametre arterijske krvi (pH, parcijalni pritisak kiseonika, parcijalni pritisak ugljen-dioksida, bikarbonate, zasićenost krvi kiseonikom, bazni eksces, kao i odnos parcijalnog pritiska kiseonika sa frakcijom inspiratornog kiseonika). Parametri su mjereni u tri vremena: prije, u toku $i$ poslije mehaničke ventilacije.

Rezultati Testiranjem razlika za vrijednosti parametara gasnih analiza izmjerenih poslije mehaničke ventilacije između preživjelih $i$ umrlih ispitanika dobijene su statistički značajne razlike $(p<0.05)$ za $p H, \mathrm{PaO} 2 / \mathrm{FiO} 2, \mathrm{HCO} 3$ i BE $(p H t=-2,96$; PaO2/FiO2 $t=2,78$; HCO3 $t=2,29 ; \mathrm{BE}$ $t=3,21)$.

Zaključak Na osnovu rezultata našeg istraživanja možemo zaključiti da je mehanička ventilacija integralni dio intenzivne terapije pacijenata sa akutnim pogoršanjima HOBP, sa značajnim doprinosom povoljnom ishodu nastalog akutnog oboljenja.

Ključne riječi: arterijske gasne analize, mehanička ventilacija, hronična opstruktivna bolest pluća, akutna respiratorna hiperkapnijska insuficijencija
\end{abstract}

\section{UVOD}

Hronična opstruktivna bolest pluća (HOBP) je jedan od glavnih uzroka morbiditeta i mortaliteta širom svijeta. U Evropskoj Uniji, HOBP i astma, zajedno sa pneumonijom, predstavlja treći po redu uzrok smrti. U Sjevernoj Americi, HOBP je četvrti vodeći uzrok smrti a morbiditet i mortalitet su u porastu. Glavna karakteristika ovog oboljenja je hronično ograničenje protoka vazduha koji postepeno progredira tokom nekoliko godina, $\mathrm{i}$ koje je, po definiciji, ireverzivilno [1]. Smatra se da uzrok ovog oboljenja nisu samo egzogeni faktori, nego interakcija između endogenih i egzogenih faktora. Starost, muški pol, pušenje, profesionalna izloženost prašini i nizak socioekonomski status su dobro poznati faktori rizika za nastanak HOBP [2].

U sklopu egzarcerbacije HOBP može se javiti akutna respiratorna insuficijencije. Respiratorna insuficijencija je sindrom $u$ kom respiratorni sistem ne može da izvrši jednu ili obe svoje funkcije $u$ razmjeni gasova: oksigenaciju $i$ eliminaciju ugljen-dioksida miješane venske (plućne arterijske) krvi [3,4]. Javlja se kada 
respiratorni sistem više nije u stanju da ispunjava metaboličke zahtjeve organizma. Respiratorna insuficijencija može biti akutna, koja se razvija u roku od nekoliko minuta ili sati, i hronična, koja se razvija u roku od nekoliko dana, čak meseci ili godina [3]. Respiratorna insuficijencija se može podijeliti na dva tipa: hipoksemijska (tip 1) i hiperkapnijski (tip 2), a oba tipa mogu biti akutna ili hronična. Kod hipoksemijske ARI snižena je koncentracija kiseonika u arterijskoj krvi i vrijednost $\mathrm{PaO} 2$ je manja od $8 \mathrm{kPa}(60 \mathrm{~mm} \mathrm{Hg})$ pri disanju na sobnom vazduhu, $\mathrm{PaCO} 2$ je normalan ili snižen. Hiperkapnijska ARI se karakteriše povišenom koncentracijom ugljen-dioksida i vrijednošću $\mathrm{PaCO} 2$ većom od $6,67 \mathrm{kPa}(50 \mathrm{~mm}$ $\mathrm{Hg}$ ), a hipoksemija je, u principu, uvijek prisutna [3]. Akutna hiperkapnijska respiratorna insuficijencija, s obzirom na brz nastanak, izaziva respiratornu acidozu u kojoj je vrijednost $\mathrm{pH}$ manja od 7,3, dok je kod hronične hiperkapnijske insuficijencije $\mathrm{pH}$ uglavnom tek blago snižen [5]. Ovaj tip respiratorne insuficijencije nastaje kao posljedica povećane produkcije $\mathrm{CO} 2 \mathrm{i} / \mathrm{ili}$ njegove smanjene eliminacije usljed alveolarne hipoventilacije [5].

Gasne analize arterijske krvi imaju veoma značajnu ulogu u kliničkoj opservaciji pacijenata sa akutizacijom HOBP [6]. One su tzv. zlatni standard u dijagnostikovanju i praćenju oksigenacionog i acido-baznog stanja pacijenta $[7,8]$. Klinička korisnost gasnih analiza prvenstveno zavisi od pravilne interpretacije rezultata.

Analiza počinje sa razumjevanjem $\mathrm{pH}$, te uticaja acidoze i alkaloze na tkivnu oksigenaciju.

$\mathrm{pH}$ (potentio hydrogeni) predstavlja negativan logaritam koncentracije vodonikovih $(\mathrm{H}+)$ jona. Fiziološki pH arterijske krvi iznosi 7,40; uz opseg od 7,35 -7,45. Pad arterijskog $\mathrm{pH}$ ispod 7,35 se smatra acidozom, dok se porast arterijskog $\mathrm{pH}$ iznad 7,45 smatra alkalozom [9,10,11]. Međutim, informacija o $\mathrm{pH}$ vrijednosti nije dovoljna da se utvrdi uzrok acido-bazne neravnoteže i da li organizam kompenzatorno pokušava da odgovori na nastali poremećaj. Parametri koji su krucijalni u opservaciji cjelokupnog oksigenacionog stanja pacijenta su parcijalni pritisak kiseonika $u$ arterijskoj krvi ( $\mathrm{PaO} 2)$, parcijalni pritisak ugljendioksida $\mathrm{u}$ arterijskoj krvi (PaCO2), zasićenost arterijske krvi kiseonikom (SaO2), bikarbonati
(HCO3), bazni eksces (BE) kao i odnos parcijalnog pritiska kiseonika arterijske krvi i frakcije inspiratornog kiseonika ( $\mathrm{PaO} 2 / \mathrm{FiO} 2)$.

Parcijalni pritisak kiseonika $(\mathrm{PaO} 2)$ i parcijalni pritisak ugljen-dioksida $(\mathrm{PaCO} 2) \mathrm{u}$ arterijskoj krvi su vrijednosti koje ukazuju na stanje respiratorne funkcije pacijenta. Fiziološka vrijednost $\mathrm{PaO} 2$ iznosi 12,67 kPa (opseg od 9,3-13,3 kPa). Snižena vrijednost $\mathrm{PaO} 2$ predstavlja hipoksemiju.U takvoj situaciji pacijent nema dovoljno kiseonika za energetski aerobni metabolizam, tako da ćelije koriste anaerobnu respiraciju uz stvaranje mliječne kiseline i razvoj ozbiljne acidoze $[9,11]$.

Normalne vrijednosti parcijalnog pritiska ugljen-dioksida u arterijskoj krvi (PaCO2) iznose od 4,67-6 $\mathrm{kPa}$ (35-45 $\mathrm{mmHg})$. Niske vrijednosti $\mathrm{PaCO} 2(<4,67 \mathrm{kPa})$ predstavljaju hipokapniju. Visoke vrijednosti $\mathrm{PaCO} 2(>6 \mathrm{kPa})$ predstavljaju hiperkapniju, koja nastala primarno usljed hipoventilacije izaziva respiratornu acidozu [11].

Zasićenje periferne krvi kiseonikom ( $\mathrm{SpO} 2$ ) $[5,12]$ se detektuje pulsnim oksimetrom. Pulsna oksimetrija omogućava sigurnu, neinvazivnu, kontinuiranu i adekvatnu procjenu zasićenja arterijske krvi kiseonikom ( $\mathrm{SaO} 2)$, na osnovu izmjerenog $\mathrm{SpO}$. Iako direktne arterijske gasne analize predstavljaju "zlatni standard" i daju nam precizne informacije o plućnoj ventilaciji, razmjeni gasova na nivou respiratorne membrane $\mathrm{i}$ acidobaznom statusu; usljed svoje invazivnosti ovaj način monitoringa nije dostupan u svim kliničkim dešavanjima. Fiziološko arterijsko zasićenje kiseonikom iznosi od 95-100\% (SaO2>95\%) i klinički predstavlja pouzdan marker snabdjevenosti tkiva kiseonikom. Pacijenti su u hipoksemiji kada je saturacija kiseonikom manja od $90 \%(\mathrm{SaO} 2<90 \%)$. Do te vrijednosti organizam kompenzatornim mehanizmima i puferskom aktivnošću hemoglobina omogućava zadovoljavajuće prenošenje kiseonika tkivima.

Bazni eksces (BE) predstavlja razliku u koncentraciji ukupnih baza i kiselina u organizmu, tj. predstavlja onu količinu kiseline ili baze koja je potrebna da se doda $\mathrm{u}$ krv da bi se $\mathrm{pH}$ vratio $\mathrm{u}$ fiziološku vrijednost. Referentni nivo BE iznosi od $-2 \mathrm{mEq} / \mathrm{L}$ do $+2 \mathrm{mEq} / \mathrm{L}$. Ukoliko je bazni ekces negativniji $(<-2 \mathrm{mEq} / \mathrm{L})$, to znači da u organizmu postoji višak kiselina odnosno razvila se acidoza. Obrnuto, što je BE pozitivniji $(>+2 \mathrm{mEq} / \mathrm{L}), \mathrm{u}$ organizmu postoji višak baza odnosno razvila se 
alkaloza. Praktično, negativan BE je aktuelni bazni deficit bikarbonata; neke laboratorije ga određuju kao poseban acido-bazni parametar [11,13].

Joni bikarbonata (HCO3) predstavljaju metaboličku komponentu acido-baznih parametara. Referentne vrijednosti $\mathrm{HCO} 3$ u vanćelijskoj tečnosti, odnosno krvnoj plazmi iznose od 22-26 $\mathrm{mEq} / \mathrm{L}$. HCO3>26 mEq/L indukuju metaboličku alkalozu, dok $\mathrm{HCO} 3<22 \mathrm{mEq} / \mathrm{L}$ indukuju metaboličku acidozu [11].

Odnos parcijalnog pritiska kiseonika arterijske krvi i frakcije inspiratornog kiseonika ( $\mathrm{PaO} 2 / \mathrm{FiO} 2)$ je osnovni parametar u postavljanju dijagnoze akutnog respiratornog distres sindroma (ARDS), uz postojanje akutnih bilateralnih infiltrata na radiografskom snimku pluća. Prema Berlinskoj definiciji, ARDS se klasifikuje na: blagi ARDS $(\mathrm{PaO} 2 / \mathrm{FiO} 2<300 \mathrm{~mm} \mathrm{Hg})$, umjereni ARDS $(\mathrm{PaO} 2 / \mathrm{FiO} 2<200 \mathrm{~mm} \mathrm{Hg})$ i teški ARDS $(\mathrm{PaO} 2 / \mathrm{FiO} 2<100 \mathrm{~mm} \mathrm{Hg})$ [14].

Mehanic ka ventilacija je postupak koji omogućava pružanje vještačke podrške za razmjenu gasova u sluc ajevima kada se spontanim disanjem ne može osigurati zadovoljavajuća ventilacija, kao što je slučaj kod respiratorne insuficijencije. Glavni ciljevi mehanic ke ventilatorne podrške usmjereni su na oc uvanje alveolarne ventilacije $\mathrm{i}$ arterijske oksigenacije, održavanje odgovarajućih plućnih volumena i smanjenje disajnog rada. Postoje dvije osnovne podjele mehanic ke ventilatorne podrške: prema nac inu stvaranja inspiratorne sile (ventilacija negativnim i pozitivnim pritiskom) i prema postojanju disajnog puta (invazivna $i$ neinvazivna). Danas se uglavnom koriste mikroprocesorski mehanički ventilatori pozitivnog pritiska [15].

Fiziološki ciljevi mehaničke ventilacije:

Podrška razmjeni gasova koja je usmjerena na održavanje alveolarne ventilacije (kao najvažnije odrednice $\mathrm{PaCO} 2)$ i adekvatne oksigenacije arterijske krvi (titriranje FiO2 i PEEP-a), što podrazumijeva održavanje $\mathrm{SaO} 2$ iznad $90 \%$, odnosno $\mathrm{PaO} 2$ iznad $8 \mathrm{kPa}$.

Održavanje funkcionalnog rezidualnog kapaciteta (FRC) čime se prevenira nastajanje atelektaza.

Smanjenje disajnog rada koji može dovesti do zamora disajne muskulature i pogoršanja respiratorne funkcije [16].

\section{METODOLOGIJA}

Retrospektivnom opservacionom studijom obuhvaćeno je 30 pacijenata koji su liječeni na Klinici intenzivne medicine (KIM) za nehirurške grane Univerzitetskog kliničkog centra Republike Srpske, tokom kalendarske 2016. godine. Ispitanici su bili pacijenti sa hroničnom opstruktivnom bolesti pluća (HOBP), koji su zbog akutizacije (već hronične ARI tip 2) i razvoja hiperkapnijske respiratorne insuficijencije hospitalizovani terapijski izloženi neinvanzivnoj $\mathrm{i} / \mathrm{ili}$ invanivnoj mehaničkoj ventilaciji. Od ukupnog broja, 16 pacijenata nije preživjelo epizodu akutnog pogoršanja, dok je 14 pacijenta uspješno odvojeno od mehaničke ventilacije i premješteno na Kliniku za plućne bolesti Univerziteskog kliničkog centra RS. Kod svih ispitanika smo analizirali gasne parametre arterijske krvi ili ekvivalentne kapilarne krvi $[\mathrm{pH}$, parcijalni pritisak kiseonika $(\mathrm{PaO} 2)$, parcijalni pritisak ugljen-dioksida (PaCO2), bikarbonate ( $\mathrm{HCO} 3)$, zasićenost krvi kiseonikom (SaO2), bazni eksces (BE), kao i odnos parcijalnog pritiska kiseonika sa frakcijom inspiratornog kiseonika ( $\mathrm{PaO} 2 / \mathrm{FiO} 2)]$. Parametri su mjereni u tri vremena: neposredno prije mehaničke ventilacije (na prijemu), u toku mehaničke ventilacije (sredina hospitalizacije) i poslije mehaničke ventilacije (na otpustu). Navedeni parametri mjereni su na aparatu RAPIDPoint ${ }^{\circledR} 500$ za analizu gasnih parametara krvi. Uzorci arterijske ili ekvivalentne kapilarne krvi vađeni su u toku hospitalizacije i analizirani na navedenom aparatu, odmah po uzorkovanju na Klinici intenzivne medicine.

Opservacionom analizom kompletne medicinske istorije navedenih pacijenata dobijeni su podaci koji su sistematizovani i obrađeni $u$ statističkom programu SPSS 15.0 for Windows. Rezultati su analizirani metodama deskriptivne i analitičke statistike.

$\mathrm{Za}$ opis parametara od značaja koristili smo uzoračku aritmetičku sredinu i standardnu devijaciju aritmetičke sredine (Mean \pm SD). Za testiranje značajnosti razlika uzoračkih aritmetičkih sredina koristili smo T-test za zavisne uzorke, uz 5\% nivo značajnosti $(\mathrm{p}<0.05$ se smatralo statistički značajnom razlikom).

Snaga veze za uzoračke parametre u odnosu u tri vremena mjerenja, kod preživjelih i umrlih 
ispitanika procjenjivana je na osnovu Pirsonovog (Pearson) koeficijenta korelacije (r).

\section{REZULTATI}

Od ukupno 30 ispitanika uključenih u istraživanje, bilo je 17 muškaraca (57\%) i 13 žena (43\%). Prosječna starost ispitanika bila je 69,37 godina (opseg 56-85 godina). Od ukupnog broja, 16 ispitanika $(53,3 \%)$ nije preživjelo epizodu akutnog pogoršanja HOBP, dok je njih 14 (46,6\%) preživjelo i uspješno odvojeno od mehaničke ventilacije.

Srednje vrijednosti (Mean \pm SD) parametara arterijskih gasnih analiza u tri vremena mjerenja (prije, u toku, poslije mehaničke ventilacije) date su u tabeli 1 , uz grafičke prikaze njihovog odnosa kod preživjelih i umrlih ispitanika (grafikoni 1-7). Testiranjem razlika za vrijednosti parametara gasnih analiza izmjerenih poslije mehaničke ventilacije između preživjelih i umrlih ispitanika (u odnosu na ishod akutizacije bolesti) dobijene su statistički značajne razlike $(\mathrm{p}<0.05)$ za $\mathrm{pH}$, $\mathrm{PaO} 2 / \mathrm{FiO} 2, \mathrm{HCO} 3$ i BE $(\mathrm{pH} \mathrm{t}=-2,96 ; \mathrm{PaO} 2 / \mathrm{FiO} 2$ $\mathrm{t}=2,78 ; \mathrm{HCO} 3 \mathrm{t}=2,29 ; \mathrm{BE} \mathrm{t}=3,21)$.

Tabela 1. Srednje vrijednosti (Mean $\pm S D)$ parametara arterijskih gasnih analiza u tri vremena mjerenja (prije, u toku i poslije mehaničke ventilacije) u ukupnom uzorku ispitanika

\begin{tabular}{llll}
\hline \hline $\begin{array}{c}\text { Parametri } \\
\text { arterijskih } \\
\text { gasnih analiza }\end{array}$ & $\begin{array}{c}\text { Prije } \\
\text { mehaničke } \\
\text { ventilacije }\end{array}$ & $\begin{array}{c}\text { Tokom } \\
\text { mehaničke } \\
\text { ventilacije }\end{array}$ & $\begin{array}{c}\text { Poslije } \\
\text { mehaničke } \\
\text { ventilacije }\end{array}$ \\
\hline \hline $\mathrm{pH}$ & $7,22 \pm 0,17$ & $7,33 \pm 0,16$ & $7,29 \pm 0,19$ \\
\hline $\mathrm{PaCO} 2(\mathrm{kPa})$ & $9,30 \pm 3,12$ & $7,67 \pm 2,06$ & $8,25 \pm 3,66$ \\
\hline $\mathrm{PaO} 2(\mathrm{kPa})$ & $8,92 \pm 7,15$ & $7,66 \pm 1,69$ & $6,50 \pm 1,57$ \\
\hline $\mathrm{HCO} 3(\mathrm{mEq} / \mathrm{L})$ & $28,32 \pm 8,69$ & $31,05 \pm 9,98$ & $29,10 \pm 8,95$ \\
\hline $\mathrm{BE}(\mathrm{mEq} / \mathrm{L})$ & $-1,28 \pm 9,64$ & $3,45 \pm 10,45$ & $1,03 \pm 10,07$ \\
\hline $\mathrm{SaO} 2 \%)$ & $78,23 \pm 16,81$ & $85,46 \pm 11,52$ & $74,40 \pm 18,16$ \\
\hline $\mathrm{SaO} 2 / \mathrm{FiO} 2$ & $1,69 \pm 0,86$ & $1,52 \pm 0,80$ & $1,20 \pm 0,50$ \\
\hline
\end{tabular}

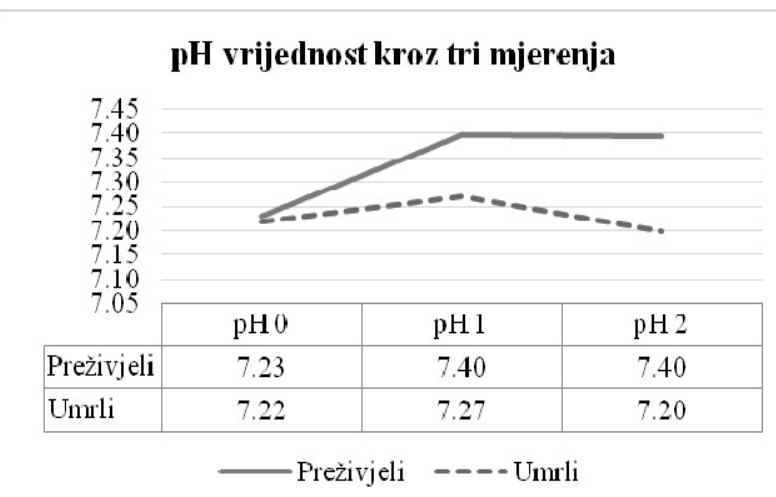

Grafikon 1. Odnos srednjih vrijednosti pH kroz tri mjerenja za preživjele i umrle ispitanike

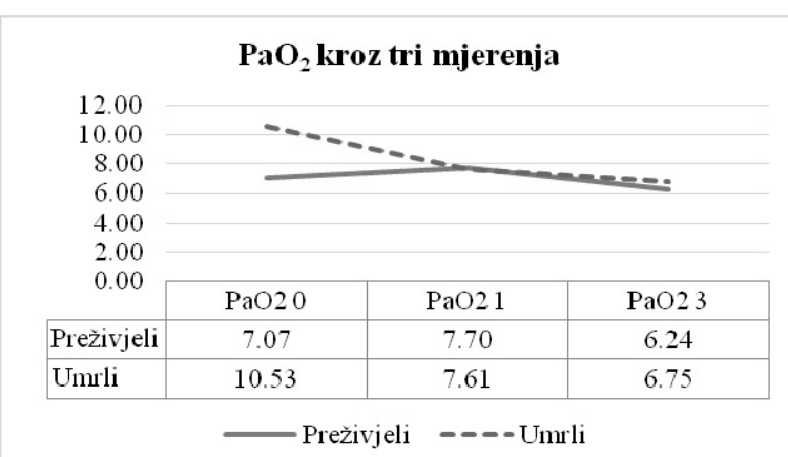

Grafikon 2. Odnos srednjih vrijednosti PaO2 kroz tri mjerenja za preživjele i umrle ispitanike

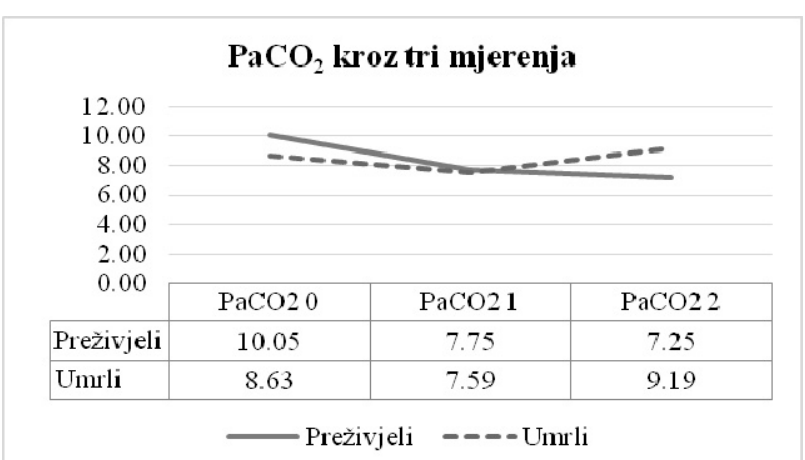

Grafikon 3. Odnos srednjih vrijednosti PaCO2 kroz tri mjerenja za preživjele i umrle ispitanike

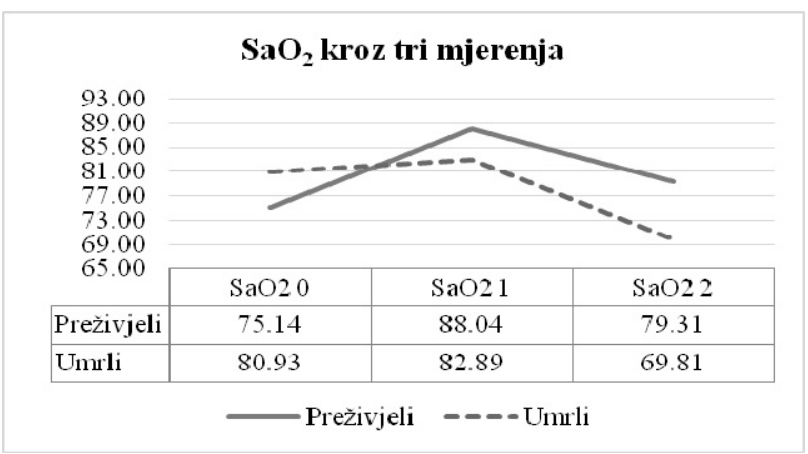


Grafikon 4. Odnos srednjih vrijednosti SaO2 kroz tri mjerenja za preživjele i umrle ispitanike

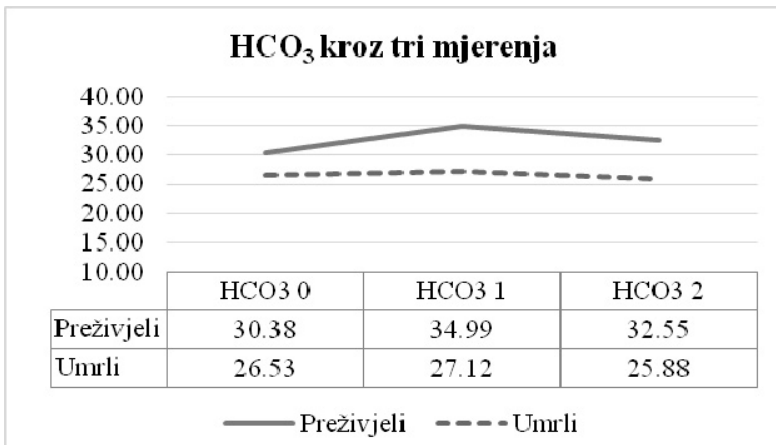

Grafikon 5. Odnos srednjih vrijednosti HCO3 kroz tri mjerenja za preživjele i umrle ispitanike

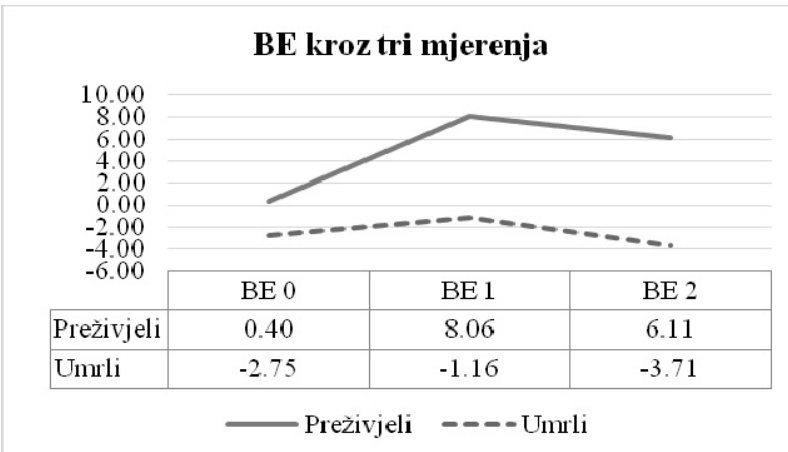

Grafikon 6. Odnos srednjih vrijednosti BE kroz tri mjerenja za preživjele i umrle ispitanike

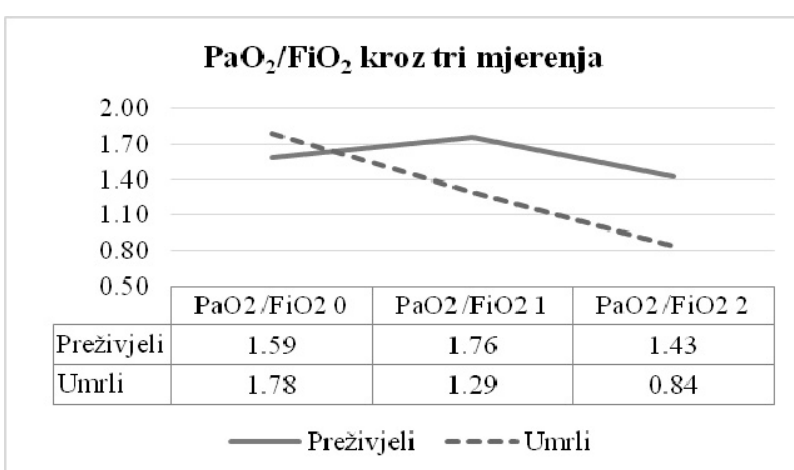

Grafikon 7. Odnos srednjih vrijednosti PaO2/FiO2 kroz tri mjerenja za preživjele i umrle ispitanike

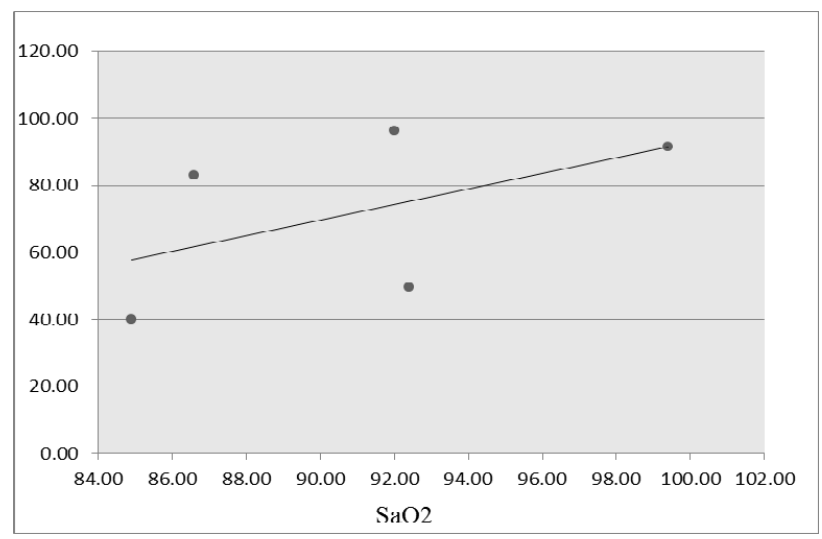

Grafikon 8. Korelacije za SaO2 kod umrlih i preživjelih ispitanika (mjerenje u toku mehaničke ventilacije)

Testiranjem korelacije preživjelih ispitanika koji su bili na invanzivnoj mehaničkoj ventilaciji u odnosu na različita vremena mjerenja, dobili smo sljedeće Pirsonove koeficijente korelacije:

za parametar $\mathrm{pH}$, u odnosu na prvo i drugo mjerenje: $r=0,84$ odnosno postoji visoka linearna korelacija (grafikon 9)

za parametar $\mathrm{PaO} 2 / \mathrm{FiO} 2$, u odnosu na drugo i treće mjerenje: $\mathrm{r}=-0,81$ odnosno postoji visoka linearna korelacija (grafikon 10)

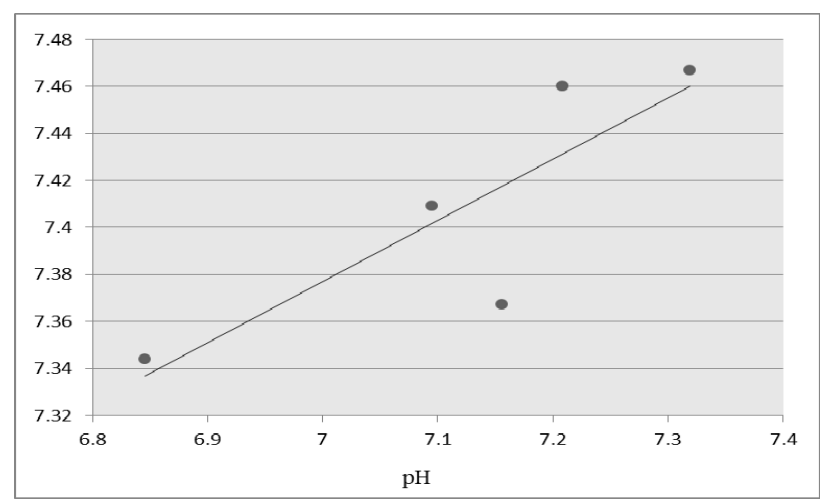

Grafikon 9. Korelacija preživjelih ispitanika koji su bili na invanzivnoj mehaničkoj ventilaciji za parametar pH, u odnosu na prvo i drugo mjerenje 


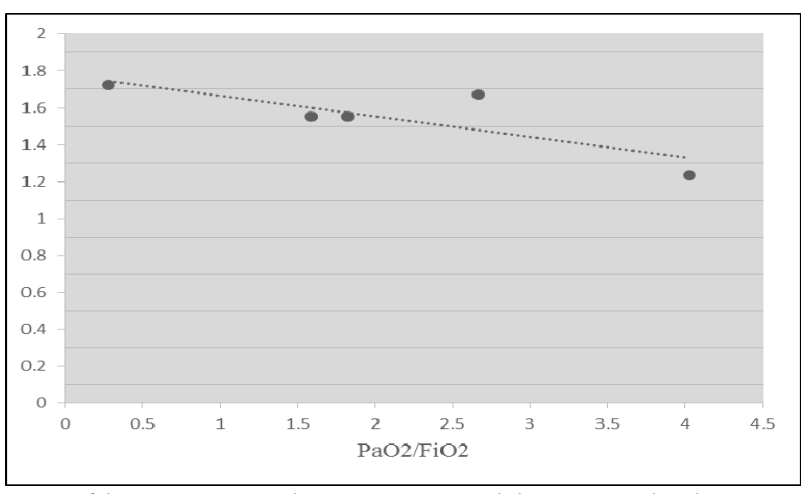

Grafikon 10. Korelacija preživjelih ispitanika koji su bili na invanzivnoj mehaničkoj ventilaciji za parametar PaO2/FiO2, u odnosu na drugo i treće mjerenje

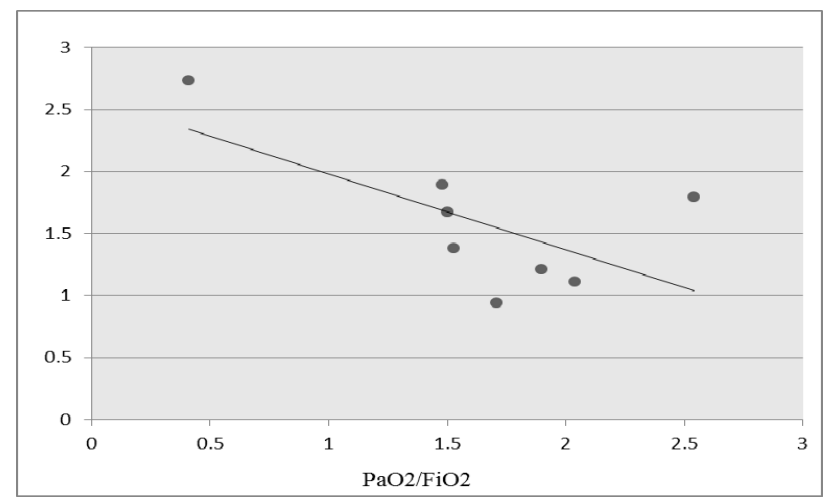

Grafikon 11. Korelacija preživjelih ispitanika koji su bili na neinvanzivnoj mehaničkoj ventilaciji za parametar PaO2/FiO2, u odnosu na prvo i drugo mjerenje

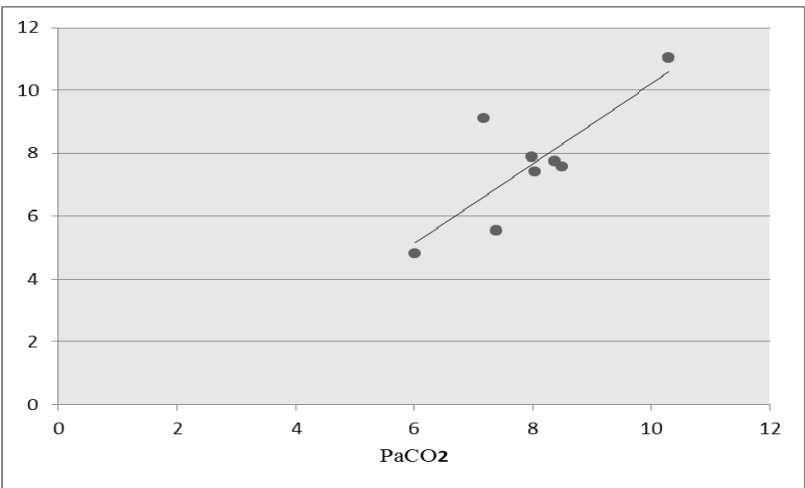

Grafikon 12. Korelacija preživjelih ispitanika koji su bili na neinvanzivnoj mehaničkoj ventilaciji za parametar PaCO2, u odnosu na drugo i treće mjerenje

\section{DISKUSIJA}

Za gasne parametre $u$ provedenom istraživanju korišteni su uzorci arterijske i kapilarne krvi. Punkcija arterije nosi rizik od komplikacija, kao što su hematomi, infekcije, arterijska tromboza i embolizacija sa posljedičnim ishemijskim oštećenjima. Osim toga, sam postupak arterijske punkcije može biti tehnički težak za izvođenje. Iz tehničkih teškoća i komplikacija arterijske punkcije proizašli su alternativni načini procjene [17]. Honarmand i Safavi su poredili vrijednosti parametara arterijske i kapilarne krvi ispitanika s akutnom respiratornom insuficijencijom koji su liječeni na odjeljenju intenzivne njege i dokazali da postoji značajna korelacija između posmatranih parametara gasnih analiza [18]. Vezu između arterijske i kapilarne krvi ispitivali su McGilivray i saradnici i dokazali da kapilarna krv može da bude odgovarajuća zamjena arterijskoj krvi u procjeni oksigenacionog stanja pacijenta [19].

Rezultati naše studije pokazuju da su za vrijednosti parametara gasnih analiza izmjerenih poslije mehaničke ventilacije između preživjelih i umrlih ispitanika dobijene statistički značajne razlike za $\mathrm{pH}, \mathrm{PaO} 2 / \mathrm{FiO} 2, \mathrm{HCO} 3$ i $\mathrm{BE}(\mathrm{pH} \mathrm{t}=-$ 2,96; $\mathrm{PaO} 2 / \mathrm{FiO} 2 \quad \mathrm{t}=2,78 ; \quad \mathrm{HCO} 3 \quad \mathrm{t}=2,29 ; \quad \mathrm{BE}$ $\mathrm{t}=3,21$ ). Ovi rezultati jasno ukazuju na pozitivne terapijske efekte mehaničke ventilacije.

$\mathrm{Za}$ razumijevanje specific nosti primjene mehanic ke ventilatorne podrške $u$ raznim patološkim stanjima, pa tako i u HOBP, važno je dobro poznavati osnovne patofiziološke mehanizme i glavne parametre ventilacije koji zajedno određuju adekvatnost razmjene gasova, čime utiču na $\mathrm{PaO} 2$ i $\mathrm{PaCO} 2$. Na vrijednost $\mathrm{PaCO} 2$ najviše utic e frekvencija disanja te produkcija $\mathrm{CO} 2 \mathrm{u}$ toku metaboličkih procesa. S druge strane, $\mathrm{PaO} 2$ određen je najviše vrijednošću PEEP-a i FiO2, dok dopremanje kiseonika tkivima (DO2) zavisi od $\mathrm{SaO} 2$, vrijednosti hemoglobina $\mathrm{i}$ minutnog src anog volumena. Akutne egzacerbacije HOBP predstavljaju najc ešće prouc avanu indikaciju za primjenu neinvazivne ventilacije (NIV) [20]. Meta analiza Keena i saradnika pokazala je da NIV, uz standardnu terapiju kod pacijenata $\mathrm{s}$ akutnim pogoršanjem HOBP, smanjuje uc estalost endotrahealne intubacije (28\% redukcija rizika), skraćuje dužinu boravka u bolnici (4,57 dana), i mortalitet tokom bolnic kog lijec enja (10\% redukcija rizika) [21]. NIV u akutnoj egzacerbaciji HOBP dozvoljava sigurnu primjenu kiseonika $\mathrm{s}$ dobrom kontrolom $\mathrm{PaCO} 2$ kod većine bolesnika. Oprez je potreban kod bolesnika $\mathrm{s}$ vrlo teškom 
hiperkapnijom. Jones i sar. su pokazali da primjenom NIV hiperkapnija ima tendenciju pada kod bolesnika s nižim poc etnim $\mathrm{PaCO} 2$, dok kod onih s visokim vrijednostima $\mathrm{PaCO} 2$, hiperkapnija i dalje raste. Ova studija govori u prilog tome da se pacijenti sa jako visokim vrijednostima $\mathrm{PaCO} 2$ c esto teško ventiliraju i da je kod njih saradnja tokom primjene NIV otežana [22].

NIV može pomoći u odvajanju bolesnika od invazivne mehanic ke ventilacijske podrške, posebno HOBP bolesnika sa akutnim pogoršanjem hronične respiratorne insuficijencije. Nava i sar. su u svoje istraživanje ukljuc ili 68 HOBP bolesnika $\mathrm{s}$ teškim akutnim pogoršanjem hronic ne respiratorne insuficijencije (prosjec ni $\mathrm{PaCO} 2$ bio je 94,2 +/- 24,2 mm Hg, a pH 7,18 +/- 0,06.). Nakon intubacije i invazivne mehaničke ventilacije $\mathrm{u}$ trajanju od dva dana, kod svih pacijenata proveden je dvosatni test spontanog disanja na Ttubus. Preovladava stav da je 48 sati invazivne mehaničke ventilacije dovoljno vremena za oporavak respiratorne muskulature kod pacijenata sa HOBP [23]. Multicentric na, prospektivna, randomizovana studija koja je provedena na dvije grupe bolesnika sa akutnim pogoršanjem HOBP, poredila je rezultate standardnog lijec enja $i$ primjene kombinacije standardnog lijec enja i NIV. NIV već nakon sat vremena znac ajno poboljšava parcijalni pritisak kiseonika $\mathrm{u}$ arterijskoj krvi (PaO2) i pH, smanjuje stepen encefalopatije i frekvenciju disanja u odnosu na standardni medikamentozni pristup. $U$ grupi bolesnika koji su liječeni NIV bila je rjeđa potreba $\mathrm{za}$ endotrahealnom intubacijom $\mathrm{i}$ invazivnom ventilacijom (26\% prema $74 \%$; p $<0,001)$, bilo je znac ajno manje komplikacija lijec enja (14\% prema $45 \%$; $<<0,01)$ i kraća hospitalizacija $(23 \pm$ 17 dana prema $35 \pm 33$ dana; $p<0,02$ ). Bolesnici koji su bili tretirani invazivnom ventilacijom (IV) imali su znac ajno veću smrtnost ( $9 \%$ prema $29 \%$; $\mathrm{p}<0,02)[24]$.

U provedenom istraživanju od ukupnog broja ispitanika, njih 11 (37\%) je bilo na IV, 9 ispitanika $(30 \%)$ na NIV. Na kombinovanoj ventilaciji je bilo 10 ispitanika (33\%), od čega je 9 ispitanika (90\%) započelo NIV pa prešlo na IV, a samo jedan ispitanik (10\%) je započeo sa IV i prešao na NIV. Prosječna dob ispitanika kod kojih je uključena IV iznosila je 68,45 godina, a kod onih na NIV 68,44 godina, dok je kod ispitanika koji su započeli terapiju sa NIV i prešli na IV prosječna starost bila 70,10 godina. To nam ukazuje da je kod pacijenata starije životne dobi započeta NIV terapija zahtijevala invazivniji pristup i intubaciju. Postoji porast upotrebe NIV u ARI od 3,8 do 10,1\%, dok se upotreba invazivne mehaničke ventilacije smanjuje sa 48,5 do $42,1 \%$. NIV se češće primjenjuje kod pacijenata preko 85 godina starosti $(12,7 \%)$ u odnosu na mlađe $(7 \%)$, i oni su pogodniji za taj oblik ventilacije $[25,26]$.

Rezultati provedene studije djelimično se mogu objasniti prisustvom komorbiditeta. Nažalost, ne postoji univerzalna definicija komorbiditeta. Tradicionalno komorbiditeti su definisani kao koegzistirajuće bolesti od interesa. Kod HOBP ova definicija postaje problematična jer pojedine bolesti mogu biti posljedica osnovnog oboljenja. Primjeri takvih komorbiditeta su kardiovaskularne bolesti, karcinom pluća i osteoporoza [27]. Angina, katarakta i osteoporoza imaju učestalost veću od $1 \%$ u prvoj godini HOBP [28, 29]. Gorini i sar. su pokazali da je od ukupnog broja pacijenata sa HOBP hospitalizovanih u jedinici intenzivne njege samo $14 \%$ pacijenata zahtjevalo invazinu mehaničku ventilaciju. Pacijenti uključeni u tu studiju imali su preko 75 godina i $55 \%$ pacijenata iz te grupe imao je bar jedan komorbiditet [30].

$\mathrm{U}$ provedenom istraživanju od 11 ispitanika koji su bili na IV, njih $6(54,4 \%)$ nije preživjelo. Mortalitet u grupi koja je bila na NIV je iznosio $11,11 \%$, dok je u grupi koja je imala kombinovanu mehaničku ventilaciju mortalitet bio najviši, iznosio je $90 \%$. Studija Seneff-a i sar. je pokazala veću stopu smrtnosti kod pacijenata sa HOBP kod kojih je primjenjena NIV, koja je iznosila 21\%, dok je stopa smrtnosti pacijenata sa HOBP kod kojih je primjenjena IV bila manja i iznosila $32 \%$ [31].

U našoj studiji na osnovu rezultata korelacije preživjelih ispitanika koji su bili na invanzivnoj i na neinvazivnoj mehaničkoj ventilaciji, a u odnosu na različita vremena mjerenja, dobili smo određene linearne povezanosti. Kod preživjelih pacijenata tretiranih IV vrijednost $\mathrm{PaO} 2 / \mathrm{FiO} 2$ je pokazala visoko linearan odnos u poređenju drugog i trećeg mjerenja $(r=-0,81)$. Ovaj indeks je $u$ toku ventilacije bio u porastu, dok je nakon ventilacije pokazao linearni pad, što ukazuje na korisnost IV. Slični su rezultati kada su u pitanju preživjeli pacijenti koji su bili na NIV. U toj grupi pacijenata 
vrijednost ovog indeksa se djelimično linearno mijenjala u odnosu na drugo i treće mjerenje $(r=$ $-0,65)$, sa padom vrijednosti nakon odvajanja od respiratora. Osim toga, ustanovljena je i visoka korelacija za vrijednost $\mathrm{PaCO} 2$ kod preživjelih ispitanika tretiranih NIV, u poređenju drugog $\mathrm{i}$ trećeg mjerenja $(\mathrm{r}=0,81)$. Kod ovih ispitanika $\mathrm{PaCO} 2$ je bio u padu, u toku i nakon mehaničke ventilacije. Takvi rezultati ukazuju da je efekat NIV na akutnu hiperkapnijsku respiratornu insuficijenciju pozitivan.

U studiji Ambrosino-a i sar. izmjerene vrijednosti $\mathrm{PaO} 2 / \mathrm{FiO} 2$ se nisu statistički razlikovale između dvije grupe pacijenata sa HOBP (preživjelih i umrlih) [32]. Proveden je niz studija koje su pratile promjenu FiO2 i reperkusije te promjene $\mathrm{u}$ arterijskoj krvi. Ciljni parametri za praćenje su bili $\mathrm{PaO} 2$ ili $\mathrm{SaO} 2$. Činjenica u kojoj se slažu sve ranije studije jeste da se vrijednosti $\mathrm{PaO} 2$ i $\mathrm{SaO} 2$ mjenjaju 20-30 minuta nakon promjene vrijednosti $\mathrm{FiO} 2$, te da je to potrebno vrijeme od početka mehaničke ventilacije do prvog mjerenja gasnih analiza arterijske krvi. Novije studije pokazuju da je kod HOBP pri promjeni FiO2 dovoljno 16 minuta mehaničke ventilacije da bi se u gasnim analizama arterijske krvi desila promjena u vrijednostima $\mathrm{PaO} 2$ i SaO2. [33, 34]

\section{ZAKLJUČAK}

$\mathrm{Na}$ osnovu rezultata našeg istraživanja možemo zaključiti da je mehanička ventilacija integralni dio intenzivne terapije pacijenata sa akutnim pogoršanjima HOBP, sa značajnim doprinosom povoljnom ishodu nastalog akutnog oboljenja. Obezbjeđuje poboljšanje oksigenacionog i acidobaznog statusa organizma. U cilju iznalaženja načina za efikasnije i kvalitetnije zbrinjavanje životno ugroženih bolesnika koji uz ostale mere iz domena intenzivne terapije zahtevaju i primenu mehaničke ventilacije, neophodna su dalja klinička istraživanja prospektivnog karaktera.

\section{LITERATURA}

1. Siafakas NM, Vereire P, Pride NB, Paoletti P, Gibson J, Howard P et al. Optimal assessment and management of chronic obstructive pulmonary disease (COPD). Eur Respir J. 1995; 8: 1398-1420.

2. Higgins MW. Epidemiology of COPD. Chest.1984; 85: 3-8S.
3. Fishman A, Elias J, Fishman J, Grippi M, Senior R. Fishman's Pulmonary Diseases and Disorders. 4th ed. New York: McGraw-Hill; 2008.

4. Vincent JL, Abraham E, Kochanek P, Moore FA, Fink MP. Textbook of Critical Care. 6th ed. Philadephia: Saunders Elsevier; 2011.

5. Gavrilović S. Akutna respiratorna insuficijencija. Respiron. 2014; 1: 35-38.

6. Ak A, Ogun CO, Bayir A, Kayis SA, Koylu R. Prediction of arterial blood gas values from venous blood gas values in patients with acute exacerbation of cronic obstructive pulmonary disease. Tohoku J Exp Med. 2006; 210(4):285-90.

7. Chu YC, Chen CZ, Lee CH, Chen CW, Chang HY, Hsiue TR. Prediction of arterial blood gas values from venous blood gas values in patients with acute respiratory failure receiving mechanical ventilation. J Formos Med Assoc. 2003; 102(8):539-43.

8. Kelly AM. Review article: Can venous blood analysis replace arterial in emergency medical care. Emerg Med Australas. 2010; 22(6):493-8.

9. Barrett KE, Barman SM, Boitano S, Brooks HL. Ganong`s Review of Medical Physiology. 24th ed. McGrawHill Medical, New York. 2012.

10. Sood P, Paul G, Puri S. Interpretation of arterial blood gas. Indian J Crit Care Med. 2010;14(2):5764.

11. Larkin BG, Zimmanck RJ. Interpreting arterial blood gases successfully. AORN J. 2015;102:344354.

12. Pretto JJ, Roebuck T, Beckert L, Hamilton G. Clinical use of pulse oximetry: Official guidelines from the Thoracic Society of Australia and New Zealand. Respirology. 2014;19:38-46.

13. Shackford SR, Mackersie RC, Hoyt DB. Base deficit as a guide to volume resuscitation. J Trauma. 1988; 28(10): 1464-67.

14. Reper P, Heijmans V. High-frequency percussive ventilation and initial biomarker levels of lung injury in patients with minor burns after smoke inhalation injury. Burns.2015; 41(1): 65-70.

15. Jukić, M., Gašparović, V., Husedžinović, I., Majerić Kogler, V., Perić, M. i Žunić, J. Intenzivna medicina 2008; Zagreb: Medicinska naklada.

16. Levison, H. Cherniack, R. M. Ventilatory cost of exercise in chronic obstructive pulmonary disease. J Appl Physiol 1968; 25: 21.

17. Novović M, Topić V. Ispitivanje povezanosti parametara gasnih analiza arterijske i venske krvi kod bolesnika s akutnim pogoršanjem hronične opstruktivne bolesti pluća. Srp Arh Celok Lek. 2012;140(7-8):436-440. 
18. Honarmand A, Safavi M. Prediction of arterial blood gas values from srterialized earlobe blood gas values in patients with mehanical ventilation. Indian J Crit Care Med. 2008;12(3):96-101.

19. McGilivray D, Ducharme FM, Charron Y, Mattimoe C, Treherne S. Clinical decision making based on venous versus capilllary blood gas values in the in the well-perfused child. Ann Emerg Med. 1999;34(1):58-63.

20. Cairo, J. M. Pilbeam's Mechanical Ventilation: Physiological and Clinical Applications. St. Louis 2012: Mosby.

21. Keenan SP, Sinuff T, Cook DJ, Hill NS. Which patients with acute exacerbation of chronic obstructive pulmonary disease benefit from noninvasive positive pressure ventilation? A systematic review of the literature. Ann Intern Med. 2003;138:861-70.

22. Esteban A, Anzueto A, Frutos F, et al. Characteristics and outcomes in adult patients receiving mechanical ventilation: a 28-day international study. JAMA 2002;287:345-55.

23. Epstein SK. Decision to extubate. Intensive Care Med 2002;28:535-46.

24. Brochard L, Mancebo J, Wysocki M, et al. Noninvasive ventilation for acute exacerbations of chronic obstructive pulmonary disease. N Engl J Med. 1995; 333:817-22.

25. Stefan MS, Shieh MS, Pekow PS, Rothberg MB, Steingrub JS, Lagu T, Lindenauer PK. Epidemiology and outcomes of acute respiratory failure in the United States, 2001 to 2009: a national survey. J Hosp Med 2013;8(2):76-82.

26. Salottolo K, Offner PJ, Orlando A, Slone DS, Mains CW, Carrick M, Bar-Or D. The epidemiology of do-not-resuscitate orders in patients with trauma: a community level one trauma center observational experience. Scand J Trauma Resusc Emerg Med 2015;23:9.

27. Sin DD, Anthonisen NR, Soriano JB, Agusti AG. Moratality in COPD: role of comorbidities. Eur Respir J. 2006; 1245-1257.

28. Mapel DW, Hurley JS, Frost FJ, Petersen HV, Picchi MA, Coultas DB. Health care utilization in chronic obstructive pulmonary disease. A casecontrol study in a health maintenance organization. Arch Intern Med 2000; 160: 2653-2658.

29. Soriano JB, Visick GT, Muellerova H, Payvandi N, Hansell AL. Patterns of comorbidities in newly diagnosed COPD and asthma in the primary care. Chest 2005; 128: 2099-2107.

30. Gorini M, Ginanni R, Villella G, Tozzi D, Augustynen A, Corrado A. Non-invasive negative and positive pressure ventilation in the treatment of acuteon chronic respiratory failure. Intensive Care Med 2004; 30:875-881.

31. Seneff MG, Wagner DP, Wagner RP, Zimmerman JE, Knaus WA. Hospital and 1-year survival of patients admitted to intensive care units with acute exacerbation of chronic obstruc- tive pulmonary disease. JAMA 1995; 274:1852-1857.

32. Ambrosino N, Foglio K, Rubini F, Clini E, Nava S, Vitacca M. Non-invasive mechanical ventilation in acute respiratory failure due to chronic obstructive pulmonary disease: correlates for success. Thorax 1995; 50: 755-757.

33. Weinreich U, Thomsen L, Hansen A, Kjærgaard S, Wagner P, Rees S. Time to Steady State after Changes in FIO2 in Patients with COPD. COPD 2013;10:405-410.

34. Wagner P. The physiological basis of pulmonary gas exchange: implications for clinical interpretation of arterial blood gases. Eur Respir J $2015 ; 45: 227-243$.

SUMMARY: Indroduction Chronic obstructive pulmonary disease (COPD) is one of the leading cause of morbidity and mortality worldwide. During the exacerbation of COPD, acute respiratory failure (ARF) type 2 may occur. This type of ARF is characterized by hypercapnia over $6.67 \mathrm{kPa}$ (50 $\mathrm{mm} \mathrm{Hg}$ ), hypoxemia and $\mathrm{pH}$ value under 7,3.

Aim of this study was to analyze influence of mechanical ventilation on oxygenation and acid-base status of ARF type 2 in patients with COPD.

Methodology This retrospective study included 30 patients who were treated at the Intensive Medicine Clinic for conservative branches of the University Clinical Center od Republic of Srpska during the year 2016. Patients had acute exacerbation of COPD (ARF type 2) and were treated with invasive or/and noninvasive mechanical ventilation. Arterial blood gases were analyzed ( $p H$, partial pressure of oxygen, partial pressure of carbon dioxide, bicarbonates, oxigen saturation, base excess and retio of arterial oxygen partial pressure to fractional inspired oxygen) before, during and after mechanical ventilation. 
Results Analysing the differences arterial blood gases after mechanical ventilation compare to disease outcome (survived and died) we got significant statistical difference $(p<0.05)$ for $z a p H$, $\mathrm{PaO} 2 / \mathrm{FiO} 2, \mathrm{HCO} 3 \mathrm{i} \mathrm{BE}$ ( $p H t=-2,96$; $\mathrm{PaO} 2 / \mathrm{FiO} 2 t=2,78$; $\mathrm{HCO} 3 t=2,29 ; \mathrm{BE} t=3,21$ ).

Conclusion Based on our results we can conclude that mechanical ventilation is an integral part of intensive care in patients with acute exacerbation of COPD, with a significant contribution to favorable disease outcome.

Key words: arterial blood gases, mechanical ventilation, chronic obstructive pulmonary disease, acute respiratory failure type 2

Zorislava Bajić

Katedra za fiziologiju,

Medicinski fakultet Univerziteta u Banjaluci,

Save Mrkalja 14, Banjaluka

Tel:051234 151; zorislava@gmail.com 